\title{
Pengaruh Interval Pemberian Air dan Jenis Pupuk Kandang Terhadap Pertumbuhan dan Hasil Tanaman Kacang Hijau (Vigna Radiata L.)
}

Suhartono ${ }^{1 *}$, Achmad Djunaedy ${ }^{1}$, Edy Suryono ${ }^{2}$, Ali Bekti Widodo ${ }^{3}$

${ }^{1}$ Prodi Agroteknologi Fakultas Pertanian Universitas Trunojoyo Madura

2 Pranata Lab. Prodi Agroteknologi Fakultas Pertanian Universitas Trunojoyo Madura

${ }^{3}$ Mahasiswa Prodi Agroteknologi Fakultas Pertanian Universitas Trunojoyo Madura

Jl. Raya Telang No 02 Kamal Bangkalan Madura 69162 Jawa Timur

*hartono unijoyo@yahoo.co.id

DOI: https://doi.org/10.21107/rekayasa.v14i2.11680

\begin{abstract}
This study aims to determine the effect of water application intervals and the type of drum fertilizer on the growth and yield of mung bean (Vigna radiata L.), This research was conducted in the greenhouse of Agrotechnology Study Program, Faculty of Agriculture, Trunojoyo University, Madura. The research design used a factorial Completely Randomized Design (CRD) which consisted of 2 factors, factor I, the water supply interval consisted of four levels, namely A1 (1 once a day), A2 (2 once a day), A3 (3 once a day), A4 (4 days).. Factor II type of manure consists of two levels, namely P1 (cow manure) and P2 (goat manure). The results showed that the water treatment interval had a significant effect on plant height parameters at all ages of observation and leaf number parameters at 27 and 39 DAP. The highest value was obtained by treatment A1. Treatment The type of manure only had a significant effect on the number of leaves at 39 DAP. There was an interaction between the treatment interval of water application and the type of manure on the parameters of wet weight, dry weight, number of pods per plant and seed weight per plant and the best treatment was P1A4.
\end{abstract}

Keywords : green beans (Vigna radiata L.), water, types of manure

\section{PENDAHULUAN}

Kacang hijau di Indonesia menempati urutan ketiga terpenting sebagai tanaman pangan legum, setelah kedelai dan kacang tanah. Untuk meningkatkan produksi kacang hijau, dengan mengoptimalkan penggunaan lahan, pemberian air sesuai dengan kebutuhan tanaman dan pemberian pupuk yang optimal. Air adalah salah satu komponen fisik yang sangat vital dan dibutuhkan dalam jumlah besar untuk pertumbuhan dan perkembangan tanaman. Sebanyak 85-90 \% dari bobot segar sel-sel dan jaringan tanaman tinggi adalah air (Maynard dan Orcott 1987). Selain itu, air berfungsi sebagai media gerak akar untuk menyerap unsur hara dalam tanah serta mendistribusikan ke seluruh organ tanaman (Sudarto et al., 2003). Doorenbos dan Kassam (1979) menyatakan bahwa untuk mempercepat pertumbuhan dan meningkatkan hasil tanaman perlu penyiraman sesuai kebutuhan.

Article History:

Received: April, 15 ${ }^{\text {th }}$ 2021; Accepted: July, $31^{\text {st }} 2021$

Rekayasa ISSN: $2502-5325$ has been Accredited by Ristekdikti (Arjuna) Decree: No. 23/E/KPT/2019 August 8th, 2019 effective until 2023
Pemberian pupuk organik sangat baik digunakan untuk memperbaiki sifat fisik, kimia dan biologi tanah, meningkatkan efektifitas mikroorganisme tanah dan lebih ramah terhadap lingkungan. Sumber pupuk organik adalah sisa tanaman dan pupuk kandang. Menurut Musnamar (2003) pupuk kandang adalah pupuk organik yang berasal dari kotoran hewan. Penggunaan pupuk kendang secara berkelanjutan dapat memberikan dampak positif terhadap peningkatan kesuburan tanah, antara lain dengan memperbaiki struktur tanah, meningkatkan mikroorganisme tanah dan meningkatkan kemampuan tanah untuk menyimpan air yang nantinya berfungsi untuk proses mineralisasi bahan organik menjadi hara yang bermanfaat bagi tanaman. Tanah yang subur akan mempermudah perkembangan akar tanaman. Akar tanaman yang dapat berkembang dengan baik akan lebih mudah menyerap air dan unsur hara

\section{Cite this as:}

Suhartono., Djunaedy, A., Suryono, E., \& Widodo, A.B. (2021). Pengaruh Interval Pemberian Air dan Jenis Pupuk Kandang Terhadap Pertumbuhan dan Hasil Tanaman Kacang Hijau (Vigna Radiata L.). Rekayasa 14 (2). 272-281. doi: https://doi.org/10.21107/rekayasa.v14i2. 11680.

(C) 2021 Suhartono 
yang tersedia di dalam tanah sehingga tanaman dapat tumbuh dan berkembang secara optimal serta menghasilkan produksi yang tinggi. Pupuk kendang sapi maupun kambing sudah banyak digunakan oleh para petani. Namun demikian, terkait dengan efektifitas masing-masing dalam meningkatkan kemampuan tanah dalam menyimpan dan menyediakan air untuk pertumbuhan dan produksi tanaman yang optimal masih perlu dilakukan penelitian lebih lanjut.

\section{METODE PENELITIAN}

Penelitian dilaksanakan di rumah kaca Prodi Agroteknologi Fakultas Pertanian Universitas Trunojoyo Madura yang terletak di Desa Telang Kecamatan Kamal Kabupaten Bangkalan Madura dengan ketinggian tempat $\pm 5 \mathrm{~m}$ dpl. Penelitian dimulai bulan Januari 2017 - Maret 2017.Alat yang digunakan dalam penelitian ini adalah polybag ukuran $40 \times 20 \mathrm{~cm}$, alat tulis, botol aqua 1,5 L, sekop, label, alat ukur (roll meter), timbangan analitik, oven, ayakan tanah, cangkul, kertas panen, dan ember. Bahan yang digunakan yaitu tanah alfisol, benih kacang hijau varietas vima 2 yang diperoleh dari Balai Penelitian Tanaman Aneka Kacang dan Umbi (Balitkabi), pupuk kandang sapi dan kambing, pupuk urea, pupuk SP-36, pupuk KCL, Furadan 3G, Dithane M-45 dan Regent 50 sc.

Penelitian menggunakan rancangan acak lengkap (RAL) faktorial terdiri dari 2 faktor. Faktor I interval pemberian air yang terdiri 4 taraf. Faktor kedua jenis pupuk kandang terdiri dari 2 taraf, sebagai berikut:

1. Interval Pemberian Air sebanyak 1 liter

A1 $=1$ hari sekali

$\mathrm{A} 2=2$ hari sekali

$\mathrm{A} 3=3$ hari sekali

A4 $=4$ hari sekali

2. Jenis Pupuk Kandang

P1 = Pupuk kandang sapi

P2 = Pupuk kandang kambing

Sehingga terdapat 8 kombinasi perlakuan, setiap perlakuan diulang 3 kali. Parameter pengamatan meliputi tinggi tanaman, jumlah daun, umur berbunga, bobot basah dan kering tanaman, jumlah polong, bobot biji pertanaman dan bobot 100 biji. Data yang diperoleh dianalisis dengan menggunakan Analisis Sidik Ragam (ANSIRA) pada taraf 5\% dan apabila ada pengaruh nyata dilanjutkan dengan Uji Beda Jarak Nyata Duncan (BJND) taraf 5\%.

\section{HASIL DAN PEMBAHASAN}

\section{Tinggi Tanaman (cm)}

Hasil analisis sidik ragam menunjukkan bahwa tidak terjadi interaksi antar faktor perlakuan terhadap parameter tinggi tanaman. Perlakuan interval pemberian air berpengaruh nyata pada umur 27 dan 39 hari setelah tanam (HST), sedangkan perlakuan jenis pupuk kandang tidak berpengaruh nyata terhadap tinggi tanaman kacang hijau pada semua pengamatan. Rata - rata tinggi tanaman dengan perlakuan interval pemberian air dan jenis pupuk kandang disajikan pada Tabel 1 .

Tabel 1.Rata - Rata Tinggi Tanaman $(\mathrm{Cm})$ Akibat Perlakuan Interval Pemberian Air dan Jenis Pupuk Kandang

\begin{tabular}{|c|c|c|c|c|}
\hline \multirow{2}{*}{ Perlakuan } & \multicolumn{4}{|c|}{ Tinggi Tanaman (cm) Pada Umur (HST) } \\
\hline & 27 & 31 & 35 & 39 \\
\hline A1 & $21,67 \quad b$ & 28,55 & 31,25 & $38,20 \mathrm{~b}$ \\
\hline $\mathrm{A} 2$ & 16,86 a & 25,31 & 27,83 & 31,29 a \\
\hline A3 & $21,25 b$ & 26,43 & 29,88 & $36,03 \mathrm{~b}$ \\
\hline A4 & $19,89 \mathrm{ab}$ & 26,22 & 29,17 & $34,50 a b$ \\
\hline BJND 5\% & * & tn & tn & * \\
\hline P1 & 20,28 & 26,76 & 29,46 & 35,17 \\
\hline $\mathrm{P} 2$ & 19,56 & 26,49 & 29,32 & 34,85 \\
\hline BJND 5\% & tn & tn & tn & tn \\
\hline
\end{tabular}

Keterangan : Angka yang diikuti huruf yang sama pada kolom yang sama tidak berbeda nyata pada uji BJND 5\% ; tn = tidak berbeda nyata

Pada Tabel 1. terlihat bahwa pada umur 27 HST dan 39 HST perlakuan A2 berbeda dengan perlakuan $\mathrm{A} 1$ dan $\mathrm{A} 3$ tetapi tidak berbeda dengan perlakuan A4. Perlakuan A1 menghasilkan tinggi tanaman paling tinggi yaitu 21,67 dan $38,20 \mathrm{~cm}$ sedangkan hasil terendah diperoleh perlakuan A2 yaitu 16,86 dan $31,29 \mathrm{~cm}$. Pada tinggi tanaman kacang hijau dengan interval 1 liter/1 hari sekali (A1) ternyata menunjukkan hasil yang lebih tinggi bila dibandingkan dengan perlakuan interval pemberian air lainnya. Kondisi ini memacu pembentukan gula yang dapat memperbesar sel-sel sehingga vakuola yang besar terbentuk. Vakuola ini secara relatif mengisap air dalam jumlah besar akibat absorbsi air ini. Keberadaan hormon perentang sel memacu selsel untuk memanjang dan dinding sel bertambah tebal. Dinding sel yang memanjang dan menebal ini terjadi sebagai akibat menumpuknya selulosa tambahan yang terbuat dari gula. Jadi kalau satu tanaman membuat sel-sel baru, pemanjangan selsel dan pembelahan sel maka akan mempercepat pertumbuhan batang, daun, dan sistem perakaran. 
Pemberian air dibawah kondisi optimum berakibat tanaman akan terhambat pertumbuhannya (tanaman menjadi kerdil) atau terlambat untuk memasuki fase vegetatif selanjutnya. Menurut Blair (1979), kandungan air tanah rendah dapat mengakibatkan rendahnya konsentrasi unsur hara yang ada di larutan tanah. Rendahnya konsentrasi unsur hara yang ada di dalam larutan tanah maka kebutuhan akan unsur hara tanaman tidak tercukupi dan akan mengakibatkan kompetisi hara antar tanaman. Begitu pula sebaliknya air yang berlebihan menyebabkan batang tanaman akan menjadi busuk. Kemampuan sel-sel tanaman dalam menyimpan air dalam dinding sel, sangat terbatas air. Air yang berlebihan menyebabkan dinding sel menjadi pecah, selanjutnya sel-sel tanaman akan mati dan tanaman akan membusuk.

\section{Jumlah Daun (Helai)}

Hasil analisis sidik ragam menunjukkan bahwa interval pemberian air berpengaruh nyata pada umur 27, 31, 35, dan 39 HST sedangkan jenis pupuk kandang berpengaruh nyata hanya pada umur 39 HST terhadap jumlah daun kacang hijau. Tidak terjadi interaksi antara kedua factor perlakuan. Rata -rata jumlah daun pada berbagai umur pengamatan disajikan pada Tabel 2.

Tabel 2. Rata - Rata Jumlah Daun (Helai) Akibat Perlakuan Interval Pemberian Air dan Jenis Pupuk Kandang

\begin{tabular}{|c|c|c|c|c|}
\hline \multirow{2}{*}{ Perlakuan } & \multicolumn{4}{|c|}{ Jumlah Daun (helai) Pada Tanaman (HST) } \\
\hline & 27 & 31 & 35 & 39 \\
\hline A1 & $7,50 \mathrm{c}$ & $14,83 \mathrm{~b}$ & $19,00 \mathrm{c}$ & $32,00 \mathrm{c}$ \\
\hline $\mathrm{A} 2$ & 5,17 a & 11,50 a & 13,67 a & 20,17 a \\
\hline $\mathrm{A} 3$ & $5,61 a b$ & 13,44 a & $16,00 \mathrm{~b}$ & $25,89 \mathrm{~b}$ \\
\hline $\mathrm{A} 4$ & $6,67 \mathrm{bc}$ & $13,67 \quad a$ & $17,33 \mathrm{bc}$ & $29,28 \mathrm{bc}$ \\
\hline BJND 5\% & * & * & * & * \\
\hline P1 & 6,22 & 13,86 & 16,33 & 25,64 a \\
\hline P2 & 6,25 & 12,92 & 16,15 & $28,03 \mathrm{~b}$ \\
\hline BJND 5\% & tn & tn & tn & * \\
\hline
\end{tabular}

Keterangan : Angka yang diikuti huruf yang sama pada kolom yang sama tidak berbeda nyata pada uji BJND 5\% ; tn = tidak berbeda nyata

Berdasarkan Tabel 2 dapat diketahui bahwa pada umur 27 HST, 35 HST dan 39 HST perlakuan A1 berbeda dengan perlakuan A2 dan A3, tetapi tidak berbeda dengan perlakuan A4. Umur 31 HST perlakuan $A 1$ berbeda dengan perlakuan $A 2, A 3$ dan A4. Perlakuan A1 menghasilkan jumlah daun paling banyak yaitu 7,50, 14,83, 19,00 dan $32,00 \mathrm{~cm}$ sedangkan hasil terendah diperoleh pada perlakuan A2 yaitu $5,17,11,50,13,67$ dan $20,17 \mathrm{~cm}$.

Daun sebagai salah satu organ tanaman berfungsi sebagai tempat terjadinya proses fotosintesis. Daun tanaman tersusun atas sejumlah sel-sel yang membentuk jaringan, yang selanjutnya kumpulan jaringan dengan fungsi sama akan membangun organ. Sel-sel dalam daun akan berkembang melalui pemanjangan sel oleh hormon perentang dalam tanaman. Keberadaan hormon perentang ini akan memacu sel-sel untuk memanjang dan dinding sel bertambah tebal. Dinding sel yang memanjang dan menebal ini terjadi sebagai akibat menumpuknya selulosa tambahan yang terbuat dari gula. Untuk dapat menciptakan kondisi yang mampu memacu sel untuk berkembang diperlukan asupan air dan hara yang cukup. Rata-rata jumlah daun pada semua umur pengamatan perlakuan A1 menunjukan hasil yang tertinggi. Perlakuan $\mathrm{P} 2$ berbeda nyata dengan perlakuan P1 pada umur pengamatan 39 HST tetapi tidak berbeda nyata pada umur pengamatan 27,31 dan 35 HST.

\section{Umur Berbunga (HST)}

Hasil analisis sidik ragam menunjukkan bahwa tidak terdapat interaksi antara faktor perlakuan terhadap parameter umur berbunga. Masingmasing faktor perlakuan tidak berpengaruh nyata terhadap parameter umur berbunga. Berdasarkan Tabel 3 rata - rata umur berbunga terlama pada perlakuan interval pemberian air cenderung diperoleh perlakuan A4 yaitu 42,22 dan pada perlakuan jenis pupuk kandang cenderung diperoleh perlakuan P2 yaitu 39,44.

Tabel 3. Rata - Rata Umur Berbunga (HST) Akibat Perlakuan Interval Pemberian Air dan Jenis Pupuk Kandang

\begin{tabular}{cc}
\hline Perlakuan & Rata - Rata Umur Berbunga (HST) \\
\hline A1 & 38,39 \\
A2 & 39,17 \\
A3 & 35,89 \\
A4 & 42,22 \\
\hline BJND 5\% & tn \\
\hline P1 & 38,39 \\
P2 & 39,44 \\
\hline BJND 5\% & tn
\end{tabular}

Ket $:$ tn $=$ tidak berbeda nyata 
Bobot Basah dan Bobot Kering Tanaman (gram)

Hasil analisis sidik ragam menunjukkan bahwa terdapat interaksi antara perlakuan interval pemberian air dan jenis pupuk kandang terhadap parameter bobot segar dan bobot kering tanaman kacang hijau. Rata - rata bobot basah dan bobot kering tanaman disajikan dalam Tabel 4.

Tabel 4. Rata - Rata Bobot Basah dan Bobot Kering Tanaman (gram) Akibat Interaksi Perlakuan Interval Pemberian Air dan Jenis Pupuk Kandang

\begin{tabular}{ccc}
\hline Perlakuan & Bobot Basah (gram) & Bobot Kering (gram) \\
\hline P1A1 & $144,65 \mathrm{bcd}$ & $57,91 \mathrm{bc}$ \\
P1A2 & $122,05 \mathrm{abc}$ & $47,58 \mathrm{bc}$ \\
P1A3 & $119,11 \mathrm{abc}$ & $47,72 \mathrm{bc}$ \\
P1A4 & $157,02 \mathrm{~d}$ & $63,47 \mathrm{c}$ \\
P2A1 & $129,43 \mathrm{bcd}$ & $49,91 \mathrm{bc}$ \\
P2A2 & $88,98 \mathrm{a}$ & $25,80 \mathrm{a}$ \\
P2A3 & $152,93 \mathrm{~cd}$ & $58,13 \mathrm{bc}$ \\
P2A4 & $112,61 \mathrm{ab}$ & $39,67 \mathrm{ab}$ \\
\hline BJND 5\% & * & * \\
\hline
\end{tabular}

Keterangan: Angka yang diikuti huruf yang sama dalam kolom yang sama berarti tidak berbeda nyata pada uji BJND 5\%

Berdasarkan Tabel 4 ternyata bahwa P1A4 memiliki nilai tertinggi untuk parameter bobot basah dan bobot kering. Pada parameter bobot basah perlakuan P1A4 berbeda dengan perlakuan $\mathrm{P} 1 \mathrm{~A} 2, \mathrm{P} 1 \mathrm{~A} 3, \mathrm{P} 2 \mathrm{~A} 2$ dan P2A4 tetapi tidak berbeda dengan perlakuan P1A1, P2A1, dan P2A3, sedangkan parameter bobot kering perlakuan P1A4 berbeda dengan perlakuan P2A2 dan P2A4 tetapi tidak berbeda dengan perlakuan $\mathrm{P} 1 \mathrm{~A} 1, \mathrm{P} 1 \mathrm{~A} 2, \mathrm{P} 1 \mathrm{~A} 3$, P2A1, dan P2A3. Menurut Suhartono et al., (2008) Bila suatu tanaman berada pada kondisi kekurangan air sebagai akibat kurangnya hujan maupun irigasi, maka proses pembentukan dan perkembangan organ akan sangat terpengaruh. Pembentukan dan perkembangan organ tanaman (daun, akar, dan batang) berhubungan dengan proses sel tanaman untuk membesar. Sel tanaman akan membesar seiring dengan menebalnya dinding sel dan terbentuknya selulosa pada tanaman. Pengaruh lainnya terkait dengan ketersediaan air, berupa transport hara dari tanah bagi tanaman. Hara yang berada dalam tanah diangkut melalui air yang terserap oleh tanaman melalui proses difusi osmosis yang terjadi. Semakin baik hara yang terserap oleh tanaman, maka ketersediaan bahan dasar bagi proses fotosintesis akan semakin baik pula.

\section{Jumlah Polong per Tanaman (buah)}

Hasil analisis sidik ragam menunjukkan bahwa terdapat interaksi antara interval pemberian air dan jenis pupuk kandang terhadap parameter jumlah polong per tanaman. Berdasarkan Tabel 5. terlihat bahwa kombinasi perlakuan P1A4 berbeda dengan perlakuan P1A3, P2A2, dan P2A4 tetapi tidak berbeda dengan perlakuan $\mathrm{P} 1 \mathrm{~A} 1, \mathrm{P} 1 \mathrm{~A} 2, \mathrm{P} 2 \mathrm{~A} 1$, dan $\mathrm{P} 2 \mathrm{~A} 3$. Nilai tertinggi diperoleh perlakuan $\mathrm{P} 1 \mathrm{~A} 4$ yaitu 22,33 dan terendah diperoleh perlakuan P2A2 yaitu 12,44 . Pemberian air pada saat pengisian polong dapat menurunkan jumlah polong yang terisi penuh. Hal ini karena kebutuhan air tanaman kacang hijau pada saat pengisian polong tidak sebanyak fase sebelumnya. Sehingga hasil polong akan lebih banyak apabila kondisi air di dalam tanah sudah berkurang. Tanaman kacang hijau menggunakan air secara efisien dan biasanya tidak merespon irigasi selama pengisian polong (Gentry, 2010). Menurut Suhartono et al., (2008) kombinasi antara ketersediaan air melalui interval pemberian air dan jenis tanah yang tepat akan mampu memberikan tunjangan kehidupan bagi pertumbuhan dan perkembangan tanaman kacang hijau yang baik. Hal ini disebabkan semua komponen pendukung bagi proses fotosintesis tersedia dengan baik. Sehingga proses fotosintesis akan menghasilkan output yang optimal utamanya berupa karbohidrat, lemak, dan protein.

\section{Bobot Biji per Tanaman (gram)}

Hasil analisis sidik ragam menunjukkan bahwa terdapat interaksi antara interval pemberian air dan jenis pupuk kandang terhadap parameter bobot biji per tanaman. Berdasarkan Tabel 5, dapat diketahui bahwa perlakuan P1A4 berbeda dengan perlakuan P1A2, P1A3, P2A2, P2A4 tetapi tidak berbeda dengan perlakuan P1A1, P2A1, P2A3. Rata - rata tertinggi diperoleh perlakuan P1A4 yaitu 19,40 dan rata - rata terendah diperoleh perlakuan P2A2 yaitu 7,66. Menurut Tawakkal (2009), semakin tinggi pemberian pupuk kandang kotoran sapi yang diberikan meningkatkan produksi sampai titik optimum dan menurunkan produksi setelah melewati titik optimum. Hal ini diduga karena mulai terdekomposisinya pupuk kendang. 
Tabel 5. Rata - Rata Jumlah Polong (Buah) dan Bobot Biji per Tanaman (gram) Akibat Interaksi antar Perlakuan

\begin{tabular}{ccc}
\hline Perlakuan & Jumlah Polong (buah) & $\begin{array}{c}\text { Bobot Biji } \\
\text { (gram) }\end{array}$ \\
\hline P1A1 & 19,89 bc & $19,26 \mathrm{~d}$ \\
P1A2 & 18,11 abc & $13,46 \mathrm{bc}$ \\
P1A3 & $17,22 \mathrm{ab}$ & $13,05 \mathrm{abc}$ \\
P1A4 & $22,33 \mathrm{c}$ & $19,40 \mathrm{~d}$ \\
P2A1 & $20,56 \mathrm{bc}$ & $17,24 \mathrm{~cd}$ \\
P2A2 & $12,44 \mathrm{a}$ & $7,66 \mathrm{a}$ \\
P2A3 & $20,22 \mathrm{bc}$ & $15,48 \mathrm{~cd}$ \\
P2A4 & $13,11 \mathrm{a}$ & $9,71 \mathrm{ab}$ \\
\hline BJND 5\% & * & *
\end{tabular}

Keterangan: Angka yang diikuti huruf yang sama berarti tidak berbeda nyata pada uji BJND 5\%

\section{Bobot 100 Biji (gram)}

Hasil analisis sidik ragam menunjukkan bahwa itidak terjadi interaksi antara kedua factor perlakuan. Selain itu perlakuan nterval pemberian air dan jenis pupuk kandang tidak berpengaruh nyata terhadap bobot 100 biji. Adapun rata - rata bobot 100 biji disajikan pada Tabel 6 .

Tabel 6. Rata - Rata Bobot 100 Biji (gram) Akibat Perlakuan Interval Pemberian Air dan Jenis Pupuk Kandang.

\begin{tabular}{cc}
\hline Perlakuan & Bobot 100 Biji (gram) \\
\hline A1 & 8,70 \\
A2 & 8,73 \\
A3 & 9,27 \\
A4 & 9,02 \\
\hline BJND 5\% & tn \\
\hline P1 & 8,87 \\
P2 & 8,99 \\
\hline BJND 5\% & tn
\end{tabular}

Ket $:$ tn = tidak berbeda nyata

Berdasarkan Tabel 6. dapat diketahui bahwa pada perlakuan interval pemberian air rata - rata bobot 100 biji tertinggi cenderung diperoleh perlakuan A3 yaitu 9,27 sedangkan rata - rata terendah diperoleh perlakuan A1 yaitu 8.70. Pada perlakuan jenis pupuk kandang rata - rata bobot 100 biji tertinggi cenderung diperoleh perlakuan P2 yaitu 8,99. Kekurangan air selama fase pembungaan hingga pembentukan polong akan mengakibatkan penurunan produksi. Terjadinya cekaman air selama fase vegetatif dapat mengakibatkan terjadinya penurunan produksi sebesar $4 \%$. Sedangkan apabila cekaman terjadi selama fase pembungaan hingga pembentukan polong, terjadi penurunan produksi sebesar $28 \%$. Akan tetapi apabila selama pengisian polong tidak dilakukan irigasi, maka hasil produksi akan meningkat 30\% (Abdullah, 2016).

\section{KESIMPULAN}

1. Interval pemberian air berpengaruh nyata terhadap parameter tinggi tanaman pada semua umur pengamatan dan parameter jumlah daun pada umur pengamatan 27 dan 39 HST. Nilai tertinggi diperoleh perlakuan A1.

2. Jenis pupuk kandang hanya berpengaruh nyata terhadap parameter jumlah daun pada umur pengamatan $39 \mathrm{HST}$.

3. Terjadi interaksi antara perlakuan interval pemberian air dan jenis pupuk kandang pada parameter bobot basah, bobot kering, jumlah polong per tanaman dan bobot biji per tanaman dan perlakuan yang terbaik adalah perlakuan P1A4.

\section{DAFTAR PUSTAKA}

Abdullah, A. 2016. Periode Kritis Tanaman Kacang Hijau (Vigna radiata L.) Akibat Cekaman Kekeringan. [skripsi]. Universitas Trunojoyo Madura. Bangkalan.

Anonim, 2007. Petunjuk Pemupukan. AgroMedia. Jakarta.

Andrianto, T.T dan Indarto, N. 2004. Budidaya dan Analisis Tani Kacang hijau, Kacang Hijau, Kacang Panjang. Yogyakarta : Absolut. Hal : 93

Amrullah, A. R., RA. Sidqi, Z. ZM., Slamet, S. 2008. Periode Kritis Kacang Hijau (Phaseolus aureus L.) Akibat Persaingan Dengan Gulma dan Macam Pengolahan Tanah Pada Tanah Mediteran Merah di Desa Socah Kecamatan Socah Bangkalan. Jurnal Agrovigor 1 (1) : 65 - 72

Arifin, 2002. Cekaman Air dan Kehidupan Tanaman. Universitas Brawijaya. Malang

Asona, M. 2013. Pertumbuhan dan Produksi Bayam (Amaranthus sp.) Berdasarkan Waktu Pemberian Air. Skripsi. Universitas Negeri Gorontalo.

Badan Pusat Statistik. 2011 - 2015. Jawa Timur dalam Angka. BPS Jawa Timur.

Balai Penelitian Tanaman Aneka Kacang dan Umbi. 2014. Morfologi Kacang Hijau Varietas Vima 2. Balitkabi. 
Buckman, H, O, Brady, N, C, 1982. Ilmu Tanah. Diterjemahkan Oleh Soegiman. Bharatana Karya Aksara. Jakarta.

Doorenbos, J. and A. H. Kassam. 1979. Yield Response to Water. FAO Irrigation and Drainage Paper 33. FAO, Rome.

Duke, J.A , 1991. Legumes of World Economic Importance. New York and London : Plenum Press. Hal 294

Gardner, F. P., R. B. Pearce., R. L. Mitchell. (1991). Physiologi of crop plant. Diterjemahkan oleh Herawati Susilo. Fisiologi Tanaman Budidaya. UIPress. Jakarta.

Gentry, J. 2010. Mungbean Management Guide $2^{\text {nd }}$ Edition. Departement of Employment, Economic, Development and Innovation. Australia.

Hardjowigeno, S. 2003. Ilmu Tanah. Akademi Pressindo. Jakarta.

Hartatik, W. dan L. R. Widowati. 2006. Pupuk Kandang, p. 59-82. Dalam:Simanungkalit, R. D. M., D. A. Suriadikarta, R. Saraswati, D. Setyorini,dan W. Hartatik (Eds.). Pupuk Organik dan Pupuk Hayati. Balai Penelitian Tanah. Bogor.

Jumin, H. B. 2010. Dasar-dasar Agronomi. Rajawali Pers. Jakarta.

Mardiati, T. 2007. Respon Morfologis Beberapa Varietas Kacang Tanah (Arachis Hypogea L.) Terhadap Cekaman Kekeringan [Skripsi]. Universitas Sumatera Utara. Medan.

Marsono., Sigit, P. 2001. Pupuk Akar dan Jenis Aplikasi. Penebar Swadaya. Jakarta.

Mayadewi, N. N. A. 2007. Pengaruh Jenis Pupuk Kandang dan Jarak Tanam terhadap Pertumbuhan Gulma dan Hasil Jagung Manis. Fakultas Pertanian Universitas Udayana Denpasar Bali. J. Agritop 26(4):153-159.

Maynard, G.H. and D.M. Orcott. 1987. The Physiology of Plants Under Stress. John Wiley and Sons, Inc. New York. 206 p.

Mulyana, D., C. Asmarahman dan I. Fahmi. 2011. Mengenal Kayu Jabon Merah dan Putih (2-36 h). Panduan Lengkap Bisnis dan Bertanam Kayu Jabon. Agromedia Pustaka. Jakarta. 142 hal.
Musnamar, E. I., 2003. Pupuk Organik Padat Pembuatan dan Aplikasi. Penebar Swadaya, Jakarta.

Mustakim, M. 2012. Budidaya Kacang Hijau Secara Intensif. Pustaka Baru Press. Yogyakarta. 140 hal.

Rukmana, R. 2006. Kacang Hijau Budidaya dan Pasca Panen. Kanisius. Yogyakarta.

Samekto. R. 2006. Pupuk Kandang. PT. Citra Aji Parama. Yogyakarta.

Setiawan, E. 2009. Pengaruh Empat Macam Pupuk Organik Terhadap Pertumbuhan Sawi (Brassica juncea L.). Embryo. 6(1):27 - 34.

Sillouw, D. M. dan Suhartono. 2007. Penampilan Beberapa Varietas Kacang Hijau (Vigna radiata L) Akibat Perbedaan Interval Pemberian Air [Skripsi]. Universitas Trunojoyo Madura. Bangkalan.

Sudarto, M. Zairin, Awaludin Hipi dan Ari Surahman, 2003. Pengaruh Jenis dan Dosis Pupuk Kandang Terhadap Pertumbuhan dan Produksi Jagung Manis (Zea mays saccharata Sturt). Pastura (1): $27-32$.

Suhartono., R.A. Sidqi ZZM., A. Khoiruddin. 2008. Pengaruh Interval Pemberian Air Terhadap Pertumbuhan dan Hasil Tanaman Kacang hijau (Glycine Max (L) Merril) Pada Berbagai Jenis Tanah. Embryo 5(1) : 98 - 112.

Sumarji, 2013. Laporan Kegiatan Penyuluhan Teknik Budidaya Tanaman Kacang Hijau (Vigna radiata L).Wilczek). Universitas Islam Kediri. Kediri.

Suprapto, H. S. 2002. Bertanam Kacang hijau. Penebar Swadaya. Jakarta

Tawakkal, M. L. 2009. " Respon Pertumbuhan dan Produksi Beberapa Varietas Kacang hijau (Glycine max L.). Terhadap Pemberian Pupuk Kandang Kotoran Sapi". Skripsi. Departemen Budidaya Pertanian. Fakultas Pertanian. Universitas Sumatera Utara. Medan

Williams, C. N., J. O. Uzo, W. T. H. Peregrine. 1993. Produksi Sayuran di Daerah Tropika. Terjemahan dari : Vegetable Production in the Tropics. Penerjemah : S. Ronoprawiro. Gadjah Mada University Press. Yogyakarta. 374 hal

Wiryanta. W dan Bernardinus .T. 2002. Bertanam Cabai Pada Musim Hujan. Agromedia Pustaka. Jakarta. 
288 | Suhartono et al., Pengaruh Interval Pemberian Air 